\title{
Law and the Political Economy of the World
}

\section{Citation}

David W. Kennedy, Law and the Political Economy of the World, 26 Leiden J. Int'l L. 7 (2013).

\section{Published Version}

http://dx.doi.org/10.1017/S0922156512000635

\section{Permanent link}

http://nrs.harvard.edu/urn-3:HUL.InstRepos:11222672

\section{Terms of Use}

This article was downloaded from Harvard University's DASH repository, and is made available under the terms and conditions applicable to Open Access Policy Articles, as set forth at http:// nrs.harvard.edu/urn-3:HUL.InstRepos:dash.current.terms-of-use\#OAP

\section{Share Your Story}

The Harvard community has made this article openly available.

Please share how this access benefits you. Submit a story.

\section{Accessibility}




\title{
INTERNATIONAL LEGAL THEORY
}

\section{Law and the Political Economy of the World*}

\author{
DAVID KENNEDY**
}

\begin{abstract}
The interpenetration of global political and economic life has placed questions of 'political economy' on the scholarly agenda across the social sciences. The author argues that international law could contribute to understanding and transforming centre-periphery patterns of dynamic inequality in global political economic life. The core elements of both economic and political activity - capital, labour, credit, and money, as well as public or private power and right-are legal institutions. Law is the link binding centres and peripheries to one another and structuring their interaction. It is also the vernacular through which power and wealth justify their exercise and shroud their authority. The author proposes rethinking international law as a terrain for political and economic struggle rather than as a normative or technical substitute for political choice, itself indifferent to natural flows of economic activity.
\end{abstract}

\section{Key words}

centre-periphery; international law; political economy

\section{INTRODUCTION: UNDERSTANDING THE BIG PICTURE: GLOBAL POLITICAL ECONOMY}

The visible interpenetration of global political and economic life has changed the context for international scholarly inquiry. The central questions today are not political questions - if by that we mean questions to be addressed by governments acting alone or negotiated through conventional diplomatic circuits. They are not economic questions - if by that we mean questions to be answered by the operations of markets, guided by the hand of robust competition in the shadow of regulation. Nor are they questions about the appropriate relationship between politics and economics, such as how public power might harness the economy through regulation, or how economic activity might best be supported by and freed from the public hand.

\footnotetext{
* This essay summarizes and extends a series of studies I have undertaken in the fields of international law, international economic law, comparative law, European law, the law of war, and the law of economic development which can be found on my website at www.law.harvard.edu/faculty/dkennedy/publications. I cite here only works developing examples which I highlight here and which were not cited in those prior studies. Versions of this essay were delivered at the American University of Cairo, I9 February 201 2; at King’s College London, I9 April 20I 2; and at Sciences Po Law School, Paris, I I May 20 I 2.

** David Kennedy is Manley O. Hudson Professor of Law and Director of the Institute for Global Law and Policy at Harvard Law School.
} 
The distribution of growth has displaced ideological hegemony and great-power competition as the framework for global political struggle. The global distribution of opportunities to generate and retain rents from economic activity has replaced the question whether private competition will be liberated from or defeated by interstate competition in the global economy. How gains and losses will be distributed between those who lead and those who lag and how the struggle between winners and losers will be carried out are questions best addressed by thinking of politics and economics as intertwined projects and close collaborators in the distribution of political authority and economic reward. The answer to these classic questions of political economy will be a function of the interactions among people across the world with diverse powers and vulnerabilities arising from diverse political and economic arrangements. Understanding these dynamics requires analysis of the iterative micro- and macro-processes through which conflict takes place, whether we think of that conflict initially as 'economic competition' or 'political struggle'.

The intellectual foundations for the return of political economy to academic life have been laid. The demand to understand questions of political economy has challenged the most robust analytic models in economics and political science to endogenize social, cultural, and institutional factors. Economists are reaching out to understand the institutional, social, psychological, and political arrangements which undergird global economic life. Scholars in sociology, political science, and international relations have renewed their interest in the impact of international economic arrangements on local, national, and global politics. Heterogeneous traditions in social-theory, economic, and legal scholarship have opened a window on the politics embedded in the basic operations of economic life; the interrelated nature of political and economic life in a world of global markets and local government; the mechanisms by which inequalities between leading and lagging sectors, nations, and regions are reproduced; and the modes through which 'governance', whether local, national, or global, all too often operates as an unsatisfying cover for economic dominance and political dysfunction. Heterogeneous traditions in law have uncovered the institutional roots of the global economy and polity in local and private rules with transnational effect, in informal networks and professional practice, and in the dispersed regulatory and administrative regimes of many nations and localities. They have identified the glue which binds the global economy together and the institutional forms and practices which fragment, professionalize, and disempower our politics.

It is now clear that the elements of economic life - capital, labour, credit, money, liquidity-are creatures of law. The same can be said for the elements of political lifepower and right. Law not only regulates these things, it creates them. The history of political and economic life is therefore also a history of institutions and laws. Law constitutes the actors, places them in structures, and helps set the terms for their interaction. It often provides the language - and the stakes - for economic and political struggle. As a result, legal arrangements offer a privileged window onto political economic dynamics. Academic inquiry ought to be able to trace the micro- and macro-processes through which people struggle over economic benefits and political authority in their legal entitlements and vulnerabilities. Legal analysis 
of this type could illuminate the large-scale political economic changes that are upending our world and their roots in the quotidian exercise of entitlements and capabilities in the capillaries of society.

With understanding may come proposals for reform. Economies configured differently will operate differently, just as different allocations of legal capacities and authority will generate divergent polities. By tracing the impact of legal forms on the economic and political actors and activities they constitute, scholars should be able to identify choices among different political and economic trajectories. It should be possible to identify alternative, even equally efficient or democratic, modes of economic and political life with diverging patterns of inequality, alternate distributions of political power and economic benefit, more or less space for experimentation or contestation.

Nevertheless, surprisingly little scholarship in the international legal field aims to illuminate the global distribution of political authority and economic growth. It is hard to say exactly why. Much legal scholarship remains parochial, enthralled by the details of each national legal system's totemic institutions. Taken together, these institutions also structure the world's political economic order, but it is rare to trace their impact on the micro-dynamics of global economic and political interactions, let alone propose their transformation in the name of an alternate global political economic vision. The legitimation of existing institutional arrangements is repeated at the international level, where central banks, the European Union, the WTO even the United Nations - have become objects of a cult-like veneration among the academics who study their operation, no less than the modern corporate form or the various institutions facilitating investment. They simply must be honoured, appeased, and defended. This academic tendency has parallels in popular wisdom. In the United States, for example, an enormous majority can view the government as a dysfunctional part of the problem without anyone seriously proposing to alter anything about it. The government is crazy - the Constitution is sacred.

At the same time, the technical professional conventions governing scholarly production in the legal field discourage pronouncements about the large trends in global political and economic life. The trending legal scholarship is small-bore precision analytics, refining and refurbishing the existing lexicons of policy, doctrine, and theory. In my view, scholars should not shy away from developing macro-scale pictures of global political economy, if only because thinking about more technical matters often rests on broad convictions about the nature of the world which no longer hold. Take the distinction between 'advanced' and 'developing' economies. Many routine ideas about institutional forms and regulatory arrangements rest on an idea about the 'kind' of society people are talking about - one which is at the cutting edge of history, where economic and political arrangements are 'mature' and most things work, or one which still has 'a long way to go' and is plagued by anomalies. Were this frame to change, much would need to be rethought. And yet it would be more accurate today to start from the premise that all economies, including the world economy, are developing economies.

In this, a fundamental neo-liberal insight was correct: just as the ideological fault line between the First and Second Worlds no longer defines global political 
struggle, the economic fault line between an 'underdeveloped' Third World and a 'modern industrialized' First World no longer defines global economic relations. Not, however, because liberal democratic politics has become the global default or because the management of routine business cycles in deregulated markets has become the universal national economic challenge. Quite the contrary. The diversity of political arrangements has increased. All countries have political characteristics once routinely thought anomalous and there is no one 'normal' or mature form for political life. Stable and significant political regimes come in many varieties more or less authoritarian, more or less religious, more or less decentralized, more and less technocratic, with different blends of public and private economic power. Few could be said to work well when it comes to addressing large-scale issues of political economy and the distribution of growth. It is not simply that the state has been 'unbundled' or political power 'networked' across boundaries. Politics has everywhere become a diminished shadow of economics as political institutions and elites have been instrumentalized by economic interests. It is not surprising that they find themselves deadlocked - or simply disengaged - when it comes to addressing issues 'in the public interest'.

At the same time, the economic challenges characteristic of the 'developing world' have become common across the industrialized world. All economies face strategic choices between different modes of insertion in the global economy; confront challenges of inequality and structural dualism; find their economies riven with market failures, information, and public-goods problems for which they lack instruments to respond; and find themselves talking about new strategies for growth rather than the efficient management of a relatively stable business cycle. In short, the difference between the First and Third Worlds has eroded because all nations now face political, social, and economic challenges once typical of the Third World.

A portrait of the political economy of the contemporary world might begin with the observation that across the world, political authority is weaker and more dispersed, economic flows more varied. The fragmentation and dispersion of political authority has rendered economic life vulnerable to political risks from unanticipated quarters while the forces unleashed by the globalization of economic life batter political elites from everywhere and nowhere at once. This has transformed the arrangement of centres, peripheries and semi-peripheries from the age of colonialism or the Cold War. Focus on the 'rise of Asia' or the emergence of a 'multi-polar' world can make it seem that structural inequality has fallen with the demise of a world system of centre and periphery. Nothing could be further from the truth. Economic and political bargaining power remains unevenly distributed-but not along a single axis.

The dispersion of political and economic forces has ignited a rapid global process of factor price equalization and technological assimilation among what once seemed the centre and the periphery of the world system. It turns out the last two centuries were an aberration as one nation and then a small group of nations rose to unprecedented levels of relative prosperity and political influence in the wake of the Industrial Revolution. The relative hegemony of a North Atlantic political and economic centre was reinforced for a long time by everything from military power to 
the structure of the novel, from multinational industrial monopolies to Hollywood movies. This hegemony has abruptly eroded as the scientific technologies, management institutions and governance arrangements which enabled the dramatic rise of the North Atlantic have become widespread and people everywhere have become able to aspire to a refrigerator, an air conditioner, a car, and the government necessary to realize those ambitions.

But economic and political change on this scale is profoundly destructive and relative income equalization is an extremely uneven business. It certainly does not mean the elimination of income differentials. On the contrary, inequality is everywhere. A global economy is not a uniform economy. Things turn at different speeds. People are left out. People are dragged down. When people turn to their sovereigns for help, the results are terribly uneven. Some are too big to fail - others too small to count. Indeed, the public hand everywhere has become a force multiplier for leading sectors, nations, regions - as it was between nations in the colonial era. As growth here erodes incomes there and consolidates itself as political right, a proliferation of centre-periphery dynamics become visible. As a result, global political economy today rests on an accelerating social and economic dualism between leading and lagging sectors, economies, nations and populations. It is not surprising that we face a revolution of rising frustrations among the hundreds of millions who can see in, but for whom there seems no route through the screen except rebellion and spectacle. Or that we face the restive demoralization of all those whose incomes, economic opportunities, and expectations have fallen - and will likely continue to fall.

The political responses everywhere aim to protect and promote winners, sometimes with a vague promise of transfer payments to compensate losers. But the political challenge is not to find resources to pour on the winners in the hopes they will render our 'nation' competitive. Nations are no longer competing - and winners can usually take care of themselves. In a global economy, it is simply not plausible for everyone to be a highest-tech, greenest, innovation-driven knowledge economy, any more than everyone can be the lowest-wage manufacturer. These are niche market dreams that function as justifications for mobilizing resources behind the successful. They serve to defer rather than underwrite the promise to compensate. The wild horse to be ridden now is the dynamic of dualism between sectors, regions, industries - and nations. The political and economic objective ought to be productively linking those who lead with those who lag in reciprocal and virtuous cycles, rather than encouraging growth here to impoverish there in the hopes that one day the losers may be made whole.

In this essay, I encourage legal scholars to improve their ability to speak about the role of law in this kind of large-scale reordering of political and economic life. I start with the intuition that law has played a central role in two grand, mutually supportive projects which have brought global political economy to this unfortunate point. In the second section, I sketch these two projects. On the one hand, economics has everywhere been disentangled from politics and economic life disembedded from political contestation. On the other, both economics and politics have been technically consolidated whether within or across national boundaries. 
Both projects have reflected the broad ideological commitments of the policy class and both were carried out as legal and institutional undertakings, supported by the knowledge practices of dedicated professionals. Together they have generated the conditions - the agents and the structures - for a world political economy marked by an accelerating dualism between the regions, sectors, and classes to whom much and to whom little - has been given. My hope is that international legal scholars will develop the intellectual tools to help understand and unravel these dynamics.

As a step in that direction, I propose that legal scholars revitalize two intellectual traditions: the analysis of relations between 'centres' and 'peripheries' in socioeconomic systems and analysis of the role of law in the background distribution of bargaining power within such systems. In the third section of this essay, I describe how these intellectual traditions might help clarify the distribution of power and economic opportunity in what otherwise might seem a diffuse jumble of institutional and regulatory structures framing the chaotic operations of political and economic life after globalization. My claim is that reflection on the role of law in the dynamic relationship between centres and peripheries will focus attention on the crucial questions of global political economy: the dynamics of inequality; the distributions of growth; the reproduction of hierarchies within and between leading and lagging sectors, regions, nations, and cultures. Taken together, strands from these intellectual traditions - heterogeneous, institutionalist, realist, critical, sociological, postmodernist, post-Marxist, progressive - offer tools for identifying the political arrangements, discourses, institutions, and debates that structure or disrupt those dynamics and for highlighting the role of expertise in rendering them normal, carrying them out - or enabling their contestation and transformation. In the fourth section, I assess the potential for scholarly work in the international-law field to draw on these traditions to understand and help to remake the political economy of the world.

\section{THE GRAND POLITICAL ECONOMIC PROJECTS THAT BROUGHT US HERE}

\section{I. Insulate economic activity from political contestation}

The first project - the separation of economic activity from political contestation has its roots in the effort to pursue economics and politics on different scales. The economy has become global while political order remains lashed to local and territorial government structures. The result is a rupture between a local and national politics on the one hand and a global economy and society on the other. It is the relative mobility of economics and territorial rigidity of politics that has rendered each unstable. Political and economic leadership have drifted apart. A spiral has begun - as the winners lock in an ever weaker territorial politics and an ever more dominant economic order. Political leadership has everywhere become peripheral to economic management.

The machinery for a territorial politics and a deterritorialized economics is technical and legal. Economic activity can only happen on a global scale if the institutional arrangements are in place to support it, just as political activity can only be concentrated territorially if the institutions responsible for political life have 
distinct jurisdictions. At a most primitive level, private rights, understood to lie outside or before politics, travel easily - if you own something here, you own it when you get off the plane somewhere else. Public policies, the stuff of politics, do not travel, except as necessary to support the broader market. Political institutions have the legal authority to enforce private agreements and private rights established elsewhere. But they cannot regulate beyond their borders. Although your labour law may affect the economy of your neighbour, your writ does not run there. The technical distinction between exercises of public authority which support the market and those which regulate or otherwise distort the market is crucial - the one travels more easily than the other. As this distinction is interpreted and implemented across dozens of institutional settings, a professional sensibility or common sense emerges about the substantive and territorial limits of public power and about the scale and naturalness of economic flows.

As a political ruler operating in the shadow of this consensus you are a spectator as the waves set in motion by your local actions ripple across the global economy. Your interests, constituencies, and authority are defined by a series of distinctions managed and enforced by the ongoing work of various expert votaries who interpret your mandate and explicate the force of legalized economic interests. As a result, the global nature of 'problems' and the local nature of 'government', whether linked to a city, a state, or the international order itself, is not only a troubling fact to be overcome. It is the product of a very particular political economy written into a historically specific set of legal and institutional arrangements. It generates, in turn, modes of political and economic life which pull away from one another a self-confident and technical form of global economic management detached from the locations or modes of production, and a media-centred form of political discussion disconnected from the technical management of government, pursued in part as gladiatorial spectacle and in part as allegorical morality tale. Meanwhile, in the background, government has become technical by division of competences, authorities, and mandates, while economics has grown technical by consolidation in ever more rapidly interlinked and speculative markets.

The rift between economics and politics is not simply the result of an ideological commitment to their distinctiveness - a kind of 'neo-liberal' overreach. Popular discourse has been full of voices for and against a 'laissez-faire' separation of politics from economic life for more than a century. Although the professionals who build and manage the political economy of today's world sometimes argue in such hyperbolic terms, when it comes to the details where the rubber meets the road, their differences are minor. At least privately, most easily acknowledge the interpenetration of politics and economics, the unavoidable need for economic regulation and the importance of political leadership for sound economic policy. The roots for the rift between local politics and global economics lie deeper in the dynamic consequences of those everyday details and will require more to reverse than an ideological conversion.

Nor are the professional vernaculars through which the political economic order is managed based on a sharp conceptual boundary between politics and economics. Economics and politics are not powers absolute within delimited spheres, defined 
in a kind of global constitutional settlement and managed by the interpretation of formal distinctions and boundaries. Although people sometimes imagine them this way, just as it is common to imagine sharp distinctions between property entitlements - your land / my land - or political jurisdictions and competences, this is not accurate. Individual political and economic 'rights', even to property, rarely work in this kind of on-off way. The relationship between you and me is all about what each of us can do with our land that may affect the other, about the terms of our relationship rather than the demarcation of our difference. When managed by jurists or policy professionals, those terms are detailed matters of more or less, determined by the balancing of competing interests and objectives.

In the professional communities where economics and politics are carried out, this is also widely understood. Just as experts know private right and public power blend into one another in many ways, they also know that politics can be hard to distinguish from economics in any categorical sense. The practical differences between them are produced almost as a by-product of the routine professional making - and unmaking - of an infinite series of small-scale technical distinctions which can be experienced by the experts who interpret them as matters for subtle balancing rather than sharp line-drawing: between public and private, national and international, family and market, between regulations which support the market and those which distort market prices, or between acts of the state which enforce private rights and those which burden them with regulation.

Such distinctions may not, in the end, be logically or philosophically satisfying, but they often work as a practical matter, at least sufficiently that experts may find professionally satisfactory ways of distinguishing situations that seem to go 'too far' in one or the other direction. As those who manage the institutions of political economic life repeatedly find ways to draw the line in specific situations, professional traditions emerge devoted to each domain. International private law experts think differently than those focused on transnational regulation. The professions responsible for the management of public and of private law, or of market making and market regulating, have grown apart, coming to occupy different institutional sites and to speak about the world in divergent vernaculars. Over time, the divergent styles of technical interpretation in different disciplines harden the differences between domains that no one thinks distinct.

The same can be said on a larger scale of the difference between economics and politics. In some sense, the relationship between politics and economics is simply a matter of interpretation and perspective. The smallest market transaction - a T-shirt sells in Ghana - can be interpreted to illuminate the politics or the economics of the planet. Yet alternative disciplines and institutional arrangements have sprung up to reflect divergent interpretations of this same transaction. As politics and economics have become increasingly technical, they have come to be served by distinct professions operating on different scales and with different perspectives. Economists and politicians understand the scale and 'logic' of the transaction differently and embed it in a different social, institutional, and intellectual context. Their differences emerge as different styles of analysis, different default interpretations, different background assumptions. As they pursue their routine work, an intellectually 
unsatisfying distinction develops into a startling mismatch between institutional, intellectual, social, and professional domains. As a consequence, the fault line between politics and economics cannot be undone by legal fiat any more than by ideological reversal. The trick is to understand the rift between politics and economics as a project undertaken everywhere at once by professionals and experts who are simply doing their job, interpreting their competences, pursuing their interests. Only by bending the arc of their routine work will the political economy of the world be transformed.

\subsection{Consolidate both economics and politics as technically integrated fields for professional management}

The second grand project - the technical integration and consolidation of both economics and politics - has also been accomplished through a series of legal, institutional, and professional projects. They have been undertaken in the shadow of a loose consensus within the global policy class about the natural teleologies for economic and political life. The economic idea is simple. Although it is common to think of an 'economy' as something nations have - the German economy, the Japanese economy - at least for those who aspire to manage it through policy, to the extent people have also come to think of an economy as a 'market', it is difficult not also to think of an economy as something that can be scaled up or down. And to think that scaling up is generally good. Ever more people, products, resources, and ideas ought to be able to find their markets in the shadow of a common price system across ever greater distances. As a result, when putting an economy together, it is a good idea to try to link as many things together as efficiently as possible at the national, regional, and global levels. This has always been more idea than reality. Despite the prevalence of local and sectoral specificities, informal networks, oligopolies, barter, intra-enterprise trade, market failures, bottlenecks, and other anomalies, it is part of the background consciousness of ruling classes everywhere that, fundamentally, the economy is naturally becoming an ever more undifferentiated global market in which 'flows' of goods and services follow prices to more productive uses.

This idea has had dozens of practical and technical corollaries. A system of 'world prices' requires all kinds of institutional arrangements and limitations. Exchange rates must either be stable-effectively a single currency - or so fluid as to ensure they are pushed to parity by market forces. Supply chains, information channels, labour markets, investment patterns ought all to be rendered global through institutional and legal integration. Private actors - investors, employees, managers, corporations need to understand themselves as capacitated to operate across an ever larger terrain. To do so, they need to be legally disembedded from the kinds of local customary or regulatory arrangements that once made employers feel they must hire from among the members of a particular union, or corporations feel they must respond to the public interest of specific locations or constituencies. Economic entities themselves need to be reconstituted and unbundled, rendered capable of being reorganized, reframed, parcelled out for sale and redeployment. Where regulation or contract impose artificial obstacles to the vertiginous destruction and creative reinvention of economic relations, they need to be unwound. Transnational private legal 
arrangements and informal standards need to be protected from the regulatory interference of local political and judicial authorities. Territorially enforced public policy which distorts rather than supports market prices needs to be either eliminated or harmonized as part of a stable background for global market transactions. Although there is much media discussion of national economic policy, most of the work of economic management in fact consists of small-scale projects to fine-tune the institutional conditions for market efficiency on a far wider scale. These are carried out by experts working in myriad settings: national and international, public and private. So long as management is carried out in this common spirit, the locus of discussion matters little. Over time, a kind of global common sense has emerged about what governments and private actors are and do and global economic life on a large scale has been consolidated in ways which set what have come to seem the natural limits of territorial government and public law regulation.

On the political side, the dominant idea is also pretty simple. Politics is all about a 'polity' - usually a community of people associated in some way with a territory. As a result, politics does not scale the way markets do. Where economies scale horizontally, politics can more easily be deepened and rendered responsive along a vertical axis of representation and accountability. The vertical activity of rulership has become the work of a profession linked to the institutional arrangements we call government. Politics has come to mean the special domain of work performed by government, itself a collection of specialized competences. As politics matures, the work of these people becomes ever more horizontally divided along functional lines: specialists in transport policy and industrial policy and health policy, as well as political consultants, media commentators, policy advocates, and the very specific set of people we call 'politicians'.

Good governance requires that these specialists strengthen the link between policy and the public interest both by strengthening the horizontal specification of mandates or separation of powers and by intensifying the vertical mechanics of rulership through accountability, transparency, citizen empowerment, and ruler responsiveness. The perfection of the polity requires and produces a parallel transformation of both rulers and ruled through one or another form of responsive democracy and the 'rule of law'. This is also more idea than reality, but it provides an orienting frame for the work of political specialists. They should aim to perfect their special technical expertise or competence and intensify their representational links to local constituencies through mechanisms of accountability and transparency.

Unsurprisingly, politics built in the shadow of these ideas is characterized by both technical consolidation and division: separating national territories into autonomous states, separating branches of government with different competences and constituencies and separating different levels of government with degrees of relative autonomy. In each setting, political competence is about the management of divided competences, specialized knowledge, and local constituencies. At different moments, policy elites seem to become enthusiasts for a similar machinery of 'responsiveness' across the spectrum of special competences, divergent constituencies, and levels of accountability. At one moment elections and constituent service, at another, stakeholder engagement and negotiation, or transparency. The result is a 
remarkably homogeneous global political order of fragmented government and local politics, operating against the background of an economy organized to link things together by detaching them from the very spatial and communal identifications with which government struggles to intensify its connection.

Most notably, of course, this vision has animated the organization of the world's political life into the series of ostensibly analogous units called 'nation-states'. Again, more idea than reality, yet ruling political classes across the world have become convinced that the world is made up of states and that those who rule have or represent one. The popular media surely encourages the view that the day's 'politics' is focused by whatever the president - or his opponent - did. Although political leaders all speak about the distinctive and exceptional qualities of 'their' state, they also share the view that their role as leader of a city, province, ministry, or commission is analogous to all the others of its type. This double conviction analogous roles, distinctive constituencies, and specializations - is the template for their political activity despite the implausibility of both ideas. The 'roles' of heads of state or ministers differ wildly whatever the diplomatic protocol may say, just as those most committed to the distinctiveness of political jurisdictions are often those who represent them, as any trip to the Washington offices of American state representatives will quickly affirm.

Nevertheless, these ideas have spawned a series of technical and institutional projects which have consolidated a government monopoly on political life in one after another location, empowering some and disempowering others while demobilizing alternative institutional arrangements and affiliations. At the national level, for example, as the polity came to mean the state, people were reconstituted as individual citizens of specific states - a process requiring a range of technical innovations in identification from passports to voting privileges. A popular and professional vernacular of civil and human 'rights' redefined justice as an appropriate relationship between an individual and a state. The demands of linguistic and other minorities were accommodated either by recognizing their demands for political autonomy through secession or, more commonly, assimilating them into a national polity as citizens with enforceable individual and minority rights. Smaller territorial units cities, neighbourhoods, states - were placed in a hierarchical relationship to larger national units, relations between them managed by professional interpretation of doctrines like 'subsidiarity', 'states rights', 'home rule', and the like. Intermediate civic institutions that might once have played a political role - professional guilds, unions, tribes - were either assimilated to national political parties or transformed into cultural and economic rather than political institutions, their members unleashed to engage with the national political world as individuals. At the same time, the emergence of a national media created a national political conversation, reflecting the activity of government back as the privileged site of politics as political parties arose to serve as gatekeepers for the apparatus and personnel of political life. In the end, politics everywhere came to be defined as the activity of specialized people who have or aspire to have government power in states.

The fantasy arrangement of the political world into 'states' also equated world politics with the diplomatic and military conversations among people linked to 
governments, reimagined from this perspective as parallel 'sovereigns'. The development of a horizontal conversation among them, whether carried on by word or deed, led to the emergence of a transnational political class of diplomats and 'non-governmental' representatives of 'civil society' whose members understand their local and global situations to be somehow analogous. Their interaction has encouraged and has been encouraged by the emergence of a common global media conversation in which all these people may imagine themselves participating. The emergence of a transnational diplomatic class - including the transnational community of international lawyers - has reinforced a shared vernacular for international political discourse and action, fine-tuning its limits, possibilities, and directions. Indeed, the most striking thing about 'world politics' today is the extent to which it is understood to be about the relations among national institutions as they unfold among specialized professionals - diplomats, soldiers, and national political leaders. All the other social activity that occurs around the world is something else - commercial activity or cultural activity perhaps, but not 'politics'.

\subsection{The result: inequality, instability, and political dysfunction}

It might seem that a world of national politics and global economics would be ripe for conflict between the two. It is often said that in the first half of the twentieth century the struggle between them was 'won' by national politics, with catastrophic economic consequences, just as it is now sometimes said that the global economy has defeated the potential for meaningful national politics. There is something to both claims, certainly. But more interesting, I believe, are the consequences of their often unequal relationship as it has been sustained over time. If economics means efficient markets and politics means democracy and the rule of law - these all seem like good ideas. It is appealing to think that they go together naturally, or that movement toward one might start a virtuous cycle toward the other. This way of thinking is extremely common among the economic and political professionals who must manage the differences between them. When problems arise, professionals in each area typically respond by calling for more of both - ever more integrated economic markets and ever more responsive and specialized government: more democracy, more efficient markets, both promoted by more rule of law. Where their logics threaten to diverge, the professional challenge is to build intermediate institutions and doctrinal schemes for the technical accommodation of national politics to a global economy and for a satisfying management of the interface between them. The trade regime is the most obvious example - a set of economic and political commitments, doctrines and interpretive institutions designed to encourage national political support for global economic activity and economic accommodation of divergent national political settlements.

Unfortunately, technical management of the tensions between these grand projects has accelerated the distance between politics and the public interest while liberating economic life from the social and political context necessary for its successful stabilization and management, in a kind of perverse feedback loop or vicious spiral, encouraging political impotence and hyperbole alongside economic inequality and instability. Think of Europe. Politics responded to the local demand for 
growth by ceding ever more territory to a distant economic technocracy which in turn demanded ever further demobilization of local policy space in the name of the technocratic imperatives of reform and austerity until the local political arrangements began to implode. Across the world, the problems calling out for public policy attention are ever more rooted in global economic movements and ever less amenable to solution on the scale of our political life. Government everywhere is buffeted by economic forces, captured by economic interests, engaged in economic pursuits. The inability of politics to offer public-interest solutions to policy challenges has encouraged political cultures ever less interested in doing so. Politics has come to be about other things - symbolic and allegorical displays, on the one hand, and the feathering of nests, on the other.

The resulting instability of contemporary political and economic life has manifested itself in a variety of ways since the economic crisis. At the top and bottom of the world economy, people have deracinated themselves, moving ever more often across ever greater distances. In relative terms, the middle classes are the ones who have become locked to their territory. For so long the national centre of political gravity, the middle classes of the advanced industrial democracies have become a global periphery, their new political and economic impotence expressing itself in ways which further destabilize political life and economic life. Governments everywhere now operate in the shadow of disenfranchised and disillusioned publics who have lost faith in the public hand - in its commitment to the 'public interest', in its sovereignty, its relevance, its capacity to grasp the levers that affect the conditions of social justice or economic possibility. In the face of integrated supply chains, global markets and financial uncertainty, workers, corporations, and banks - all turn to the nation-state for redress, bailout, support - only to find there is often little their sovereign will do. Just as the global economy has no 'commanding heights', so the political system has no sovereign centre. The institutional structure for each has been broken up. Political life has drifted into neighbourhood and transnational networks, been diffused into the capillaries of professional management, and condensed in the laser beam of media fashion, transformed into a unifying, if impotent, spectacle. From the inside looking out, one finds oneself buffeted by one thing after another - professional common sense chastens the most robust party platform and only the wholesale replacement of politicians by 'technocrats' seems capable of appeasing economic forces. From the outside looking in, however, the centre seems captured, craven, conspiratorial.

Only rarely can a good solution be reverse engineered from critical identification of the problem. Nevertheless, this interpretation of the current political economic dilemma suggests a thought experiment. What would happen were the governance professions suddenly reoriented to reversing these two large-scale projects? Imagine the daily management of political and economic life aimed in broad terms to reconnect the political and the economic by revising the sinews of legal, institutional, and intellectual life through which they have been separated. Imagine the ruling elites also aimed to reverse the technical consolidation of global economic and political life by fragmenting the space of economic activity and multiplying the modes through which politics is undertaken. These broad projects might also 
be mutually reinforcing. For example, the intermediate institutional forms which could fragment economic space and disrupt the consolidation of national political life may also open spaces for a reconnection of politics with economics.

Such a programme would be familiar to the world's leading risk managers, who have seen the dangers of overintegration in economic life. Financial risk management requires the reintroduction of stopgaps and go-slow provisions against the damage of contagion and the volatility of speculative flows. Supply-chain risk management required the reintroduction of inventories to guard against the disruptions of a tsunami here, a nuclear accident there. Imagine continuing on this path, reintroducing institutional forms for economic life linked to territory and to the constituencies whose economic and political possibilities rise and fall with their location - public unions, publicly owned enterprises, corporate forms responsive to public policy as well as shareholder profit, banking and credit reoriented to local economic development. Large-scale regional institutions - central banks, development banks - might be reorganized to be more responsive to diverse local economic and political imperatives, their investments delinked from world market benchmarks. At the same time the experts and professionals who adjust the terms of global political and economic life might aim to strengthen the potential of local politics to pursue their own path. It is not impossible to imagine how this could be done. After all, in the political economy of today's advanced industrial economies a generation or two ago, the intermediary organizations that recently came to look like pure economic irrationality - professional monopolies, corporations linked to local stakeholders, unions forcing negotiations over the forms and costs of public goods - were often also spaces of political engagement. Reinventing such arrangements would require that we reimagine law less as a common language of economic and political integration than as a shield for alternative paths and powers.

This is simply a thought experiment - a utopian heuristic. People can imagine doing it -indeed, in some areas it is already being done - although it would radically alter the background assumptions which inform the routine professional practices of both economics and politics. Thought experiments like this are important precisely because they focus attention on the large-scale background ideas experts carry around in their heads about what politics or economics are about, where they are heading, and how law fits in. If rulership professionals, including international lawyers, are to develop the analytic habits and perspectives necessary to understand and remap the political economy of the world, they will need to break free of the technical agendas which orient the work of the professions.

It is important to try. When the world's managers focus only on the technical issues of institutional form or regulatory policy which their professional disciplines mark out for attention, they are not simply rearranging the deckchairs on a vulnerable world - they are part of the process by which the world unravels. The legalization of both politics and economics makes legal institutions and professional practice the glue that constitutes these domains, allocates powers and incapacities between them, and carves the channels through which their separation accelerates. Once this begins, law progressively locks in the gains, for it is the stakes as well as the conduit for interactions between centres and peripheries. How this happens 
can be traced in the stock of social and legal entitlements each group has been allocated to participate in global economic life. As a result, I am convinced that legal scholars have much to contribute to understanding how the political economy of the world has come undone and what might be done in response. To do so, they will need to rejuvenate two intellectual traditions - the sociopolitical or socioeconomic analysis of centre-periphery dynamics, and the critical analytics first developed by legal realists and socio-legal voices a century ago and developed over the last decades by a variety of critical, progressive, and postmodernist voices. I turn now to those heterogeneous inheritances.

\section{CEntre-Periphery anAlytics AND Legal ReAlism: DOORWAYS TO POLITICAL ECONOMY}

The analysis of 'centre-periphery dynamics' has served as the portal to a variety of different political and intellectual projects over the last half-century. A brief list would include:

- A project in development economics to foreground the potential for national (or international) economic management to staunch the effects of interregional or international dependency and the 'development of underdevelopment', as scholars termed it.

- A project in international politics or international relations to comprehend the dynamics of 'neo-colonial' arrangements limiting the self-determination of newly and nominally 'independent' nations.

- A political project in cultural psychology to understand the dynamics of assimilation, self-marginalization, and rage in the periphery and complacency at the centre of what scholars called the 'world system'.

- A project of historical recovery to trace the impact of the colonial legacy in liberal internationalism and to decentre the European and North Atlantic traditions in the discipline of international law

There were certainly others. 'Centre-periphery dynamics' opens the way for so many critical projects precisely because so many mainstream frameworks edit out both the periphery and the dynamics. Attention to centre-periphery relations opens a window onto the structures of power and hierarchy in a larger system and onto the continuation of war in times of peace through the dynamics of domination and reciprocal influence among unequal actors in such a system.

Before turning to the relationship between political economy and international law, it may be helpful to review in quite general terms what it takes to think about 'centre-periphery dynamics' in a field. Most obviously, you need to identify a 'centre' and a 'periphery' - of something. There needs to be a field, a topography, a history, or a system within which something is the centre and something else is the periphery. This field provides the coherence, holds the centre and periphery in a relationship. Talking about centre-periphery dynamics forces you to say something about how 
this larger system functions and coheres. Is it an iron cage? A chaotic accident? Something in between?

For some academic and professional disciplines, it is simply obvious that what they are looking at is a 'system'. In many fields, that idea has entered popular consciousness as well. Economists think of 'economies' as systems whose dynamics can be divined and modelled. By and large, so do laypeople. The popularization of psychological ideas has made it common to think about our internal world as a dynamic economy of desires, reasons, aspirations, pressures, prohibitions, and so on. Family-therapy models crystallize the idea that families are social systems with dynamics specific to each family and common to families across the culture.

The legacy of academic thinking about international relations and international law is more ambivalent. In some sense, scholars in these fields do encourage the notion that there is an international political system and an international legal system. For almost a century, however, scholarship in both fields has also disputed the idea that these things are 'systems'. Political scientists have stressed the multiplicity and heterogeneity of political life across diverse institutional and cultural forms, the replacement of a systematic high politics by a communicative process embedded in an unpredictable and chaotic social field. For international lawyers, the point of legalizing international relations has always been to replace a political system (say, 'balance of power') with a legal order among sovereigns. Getting there has required reimagining both international politics and international law; breaking them down into functional pieces; placing them in an ongoing and diffuse process of argument and collective legitimation; dispersing them across myriad actors, stakeholders, participants in an international legal/political process; embracing a comprehensive legal pluralism. Taken together, focus on legal pluralism, fragmentation, and the dispersion of politics throughout social and institutional life has undone the idea that either politics or law coheres as a 'system'. It is as if the political system could be replaced by a legal order only at the expense of both systematicity and orderliness. The result is an open-ended process of competition among all manner of interests which sometimes manage to congeal into what can at best be interpreted as mediumscale 'systems' organizing an economic sector, region, or domain of activity, prone to overlap, conflict, and disintegration as they interact. This legacy makes it difficult to take the first step toward dynamic interpretation of centre-periphery dynamics precisely because doing so requires what seems a step back to the more primitive idea that there is, after all, some kind of system.

The erosion of professional attachment to the systematicity of global life was accompanied by the rise of a technocratic and practical sensibility that has transformed rulership. Ruling is not about grasping the controlling levers of a system or exercising what Weber famously called the vocation of politics. ${ }^{\mathrm{I}}$ Rulers now occupy functional roles, have delegated competences, deploy technical tools and instruments to address concrete problems. Rulers have become experts, spoken by their expertise. They operate in a context, but they need not attend to any larger system.

M. Weber, 'Politics as a Vocation', in Weber, Essays in Sociology (ed. H. Garth and C. Mills) (I946), 26 at 45. 
Nor are conflict and distribution central to their work - the point is rather problem solving, whether in small steps or bold gestures. Day by day, they inch toward completion of a model city, an international Potemkin village of functional equivalents for ideal-typical national political arrangements. Out there, vaguely surrounding their activity, are various constitutional arrangements, institutional settlements, political expectations, economic forces, cultural fashions - their technocratic world drifts in a haze of system fragments.

Attention to centre-periphery dynamics in this fragmented fog is a way of reawakening the idea of system and focusing on conflict, domination, hierarchy. Indeed, the only systematic element we would need to begin to make sense of global political economy is a kind of permanently floating centre-periphery dynamic which will open the door to a reimagination of the system as a system. Centreperiphery analytics constitute a systemic field by assigning positions to things 'within' it and tracing the interactions, conflicts, and hierarchies among them. Seen this way, the 'system' is less a fact in the world, held together by a constitution spelling out actors and structures, than an interpretation. A story about the way things bunch together in uneven patterns and affect one another over time. More conventional narratives are also, of course, stories. But they are stories which occlude attention to the dynamics of power and hierarchy. The point of developing a centre-periphery narrative is to juxtapose an account that foregrounds those elements, challenging the conventional accounts that somehow metabolize them.

As elements in an interpretive story, the metaphor of 'centre' and 'periphery' can refer to just about anything: ideas, regions, nations, groups. The point is the relationship - a relationship that can be spatial, temporal, or just a matter of mental emphasis. The periphery can be 'far away' from the centre, 'more backward than' or 'historically prior to' the centre, or simply less significant, less a matter of focus and attention than the centre. All these are asymmetric relationships, hierarchies.

The centre-periphery metaphor implies a model, an ideal-typical picture, of how centres and peripheries interact. Scholars have generally used the metaphor to assert relationships at once of difference and hierarchy. Things that are up to date, nearby, are also more important or privileged or powerful. Centres have more agency. The structure favours them. Centres exercise powers, get stuff, have status that is not available to peripheries. Perhaps the centre also does bad things to the periphery. Perhaps it keeps the periphery peripheral - or makes it ever more peripheral. That kind of thing is what centres do.

The danger here is the tendency to exaggerate the clarity and causal determinacy of the model - and the ability to translate generalities about 'centres and peripheries' to whatever is saddled with these labels. Although centres sometimes impoverish or oppress peripheries, sometimes they do not. Sometimes they may lift them up. And sometimes their relative positions are a function of something else entirely some other system or interest or force that keeps them in such a relationship. The trick here is to rehabilitate the idea of a system without the baggage of necessity.

Moreover, it is one thing to assert that there is a system and quite another to explain how it works. This requires spelling out with some specificity just what renders the one thing peripheral to the other; how are they differentiated in social, 
economic, cultural terms; how they then relate to one another; and how various social and material forces generate a dynamic between them. I have long found Gunnar Myrdal's extremely loose analytic framework for thinking about economic and social dynamics useful here. ${ }^{2}$ If we start with economic dualism - the city and the countryside, the wealthy north and the poorer south, the inner city and the suburbs, the industrial and agricultural sectors - it is hard to know just what will happen. Certainly good things in one can wreak havoc on the other. A wealthy region can draw investment, people, and energy toward it, making it ever more difficult for a poorer region to move ahead. But wealth in one region can also stimulate growth elsewhere. The point is that bad-or good - things in either the centre or the periphery can have a positive or a negative effect on the other. It all depends. Depends on all kinds of things - from attitudes and institutions to politics. Myrdal orients the analysis to identifying the linkages, understanding the dynamics of positive and negative effects, vicious and virtuous cycles, relatively stable equilibria, and tipping points through which good or bad things in one have an effect in the other. His method is less an analytic than a list: a list of effects that can arise between a centre and a periphery.

The dynamic dimension is crucial. Statically, it is easy to imagine that things are stable, in equilibrium. Or that the system moves as a whole - growth lifts the rich and the poor, perhaps unequally, but together. It turns out, however, that when you turn on the switch, all kinds of interactions between the centre and the periphery disrupt the equilibrium and threaten the notion of the system moving as one. When things work well, an equilibrium disrupting increase in wealth in one place can stimulate growth elsewhere. When they do not, inequalities and hierarchies may reproduce themselves or become worse. Good intentions have unanticipated bad consequences, surprising feedback loops arise, secondary effects set in, and soon we are in a vicious spiral. Virtues spawn vices. Which way things will go - or whether they will move at all in relationship to one another - depends on the linkages.

This way of thinking blunts the temptation to hunt for large-scale narratives of necessity either for the economy as a whole or for the relationship between its dual elements. The focus is on mid-level social formations. On the macro side, there is dualism - two subsystems sufficiently differentiated from one another to operate somewhat independently. And there are linkages - sinews of interaction which can strengthen and weaken. These more micro-processes develop dynamics of their own.

This is where law comes in. Legal rules and institutions are sinews of connection and distribution among subsystems. As a result, attention to law can clarify how centres and peripheries come to be differentiated, as well as the micro-processes that operate to link them. A variety of heterogeneous traditions in legal thought offer tools for identifying these linkages and the channels which structure the dynamic relations among actors in divergent starting positions. The critical and realist traditions in legal scholarship which stress the role of legal entitlements in constituting actors, allocating rents, and establishing patterns of bargaining power

See, for example, G. Myrdal, An Approach to the Asian Drama: Methodological and Theoretical Selections from Asian Drama: An Inquiry into the Poverty of Nations (I970), App. 2. 
offer a powerful lever for grasping the mid-level relationships of differentiation and influence. ${ }^{3}$ Socio-legal traditions focus attention on the impact of legal arrangements on human behaviour - and vice versa. The variety of postmodern influences which entered the legal academy over the last decades foreground the communicative, constitutive, and performative effects of law in social life. Taken together, these traditions shift analytic focus away from the structure and constitution of 'the legal order' toward the role of law, legal institutions, and legal ideas in the hard and soft distribution of entitlements, authority, and bargaining vulnerabilities among actors within an economic or political system, and to the role of law in the micro-processes of global political and economic struggle.

In this sense, centre-periphery is not a strong model of poweror dominationfocused on the identification of agency, causation, and effect. It is a model of relative positions in a field and the dynamics which develop between them over time. The point is not that the centre does this or that to the periphery. The actors here are people. The systemic element and the dynamics between centre and periphery arise from what they do. Some system of norms, ideas, and expectations, enforced in some way by violence or habit, by shame or charisma, permits actual people situated here to do this and there to do that. The power that drives the whole thing, if we can speak of power in that way, runs orthogonal to the field and is exercised as people do things in the shadow of those ideas, expectations, and authorities. Power rests with the system of entitlements that links people in relationships of relative privilege and vulnerability with the habits of society, with the ideas, aims, and identities of the participants themselves, and with the objectives and enforcement authority of the state. As people act in the shadow of these authorities and constraints, the complex reciprocal relations between centres and peripheries unfold.

The modest mid-level analytics of Myrdal are useful to develop a checklist of both salutary and perverse links, paradoxical or unexpected effects, vicious and virtuous cycles that can then unfold. A legal focus on the role of background entitlements in the socio-legal dynamics between actors in an economy or a political order is a useful heuristic for identifying the linkages. In a legal system, entitlements to rents are, broadly speaking, the glue that distributes. Finding the entitlement - and the expectations unleashed in the shadow of entitlement - identifies the hand of power. Just as finding the distributive hand of the state in the routine operations of private law adjudication highlights the presence of coercion in what may otherwise seem an equitable process of bargaining and exchange. Doctrinal and institutional arrangements encourage the accumulation of gains, reinforcing the asymmetry. Seen this way, tendentious diagnostics do not require an iron cage. Small rules and good intentions can generate entitlements that reproduce or ameliorate social inequalities as they radiate out through a system structured by centre-periphery asymmetries.

Although Myrdal developed his method to describe linkages among 'economies', it is easy to see that such an approach may also shed light on asymmetric relations

\footnotetext{
D. Kennedy, 'The Stakes of Law, or Hale and Foucault!', (I99I) XV(4) Legal Studies Forum 327.
} 
in the worlds identified as 'political'. It is common to think of law - public as well as private - as a tool for distributing political authority. Understanding the role of entitlements or legal competences in structuring asymmetric political bargaining and exchange is but a small step. Indeed, such an approach would seem altogether compatible with the disaggregated and distributed understanding of law that has come to dominate the international-law field. Myrdal's mid-level analytics embraced the disorderly pluralism and fragmentation of social, economic, and political life. That did not eliminate the potential for dualism, for linkages, for spillovers, for the capture of rents and the reinforcement of bargaining power, for vicious - or virtuous - cycles. Far from it. It just makes them harder to find, the mechanics of their operation harder to isolate. The critical and heterogeneous traditions in legal thought give us a place to look for those mechanics.

It is nevertheless surprising how rarely international-law scholars focus on the distributive impact of local, national, and international legal rules in the global economy, compared to the enormous energy devoted to the quixotic effort to explain how it all may one day add up to a coherent, constituted legal order. The explanation, I am convinced, lies in two unfortunate ideas. First, the idea that international lawyers should notfocus on issues of political economy. Economics is for someone else, politics precisely what one hopes to beat into the ploughshares of legal order. And second, the idea that questions of political economy can best be answered either by largescale narratives of historical necessity - the nature of capitalism, and so forth or by ethnographies and micro-sociological study of the impact of 'globalization' on very particular communities and transactions. The approach I propose differs from both, engaging international lawyers in questions of political economy and focusing on the middle range. The idea is to use the background world of law and legal expertise as a window for interpreting the foreground of world political economy. The hypothesis is that law offers an index of tools and stakes for interaction between centres and peripheries in the world political economic system.

This way of thinking might also illuminate asymmetric relationships among more symbolic 'systems' of ideas, disciplinary sensibilities, or national traditions. A focus on the ways in which institutional forms migrate between centres and peripheries could harness comparative legal inquiry to questions of political economy. Comparative law now oscillates between reflection on macro-questions of functional equivalence among legal cultures or patterns of influence and transplantation among broad legal traditions or 'families', on the one hand, and micro-questions of alternative technical solutions to problems common among modern industrial economies found in different national regimes, on the other. The goal of the inquiry is often either to expand the range of plausible national solutions or to search for a 'best practice' that might be generalized. In the wake of Myrdal, I would hope comparative legal scholars might rather focus on the asymmetric interactions between the legal ideas and institutions of legal cultures in centres and peripheries, and on the role of legal similarities, differences, and influences in reproducing or contesting relations between political and economic centres and peripheries.

To the extent our world is governed by the ideas and practices of experts, it may also be useful to explore the relative authority and reciprocal influences of 
ideas, disciplines or fields of expertise which are more or less dominant, prestigious, or central. In the development field, for example, there is no question economics has been in the driver's seat for more than 50 years compared to law or other social sciences. The dynamics of the relationship between economics and law in the expertise of development policy makers has some of the characteristics of a centre and a periphery. In repeated waves, an increasingly robust economic model has come to dominate the field, exogenizing law, governance, and much else, only to find itself chastened by an inability to translate its analytics successfully into policy. At such points, economics has reached out wildly to law, institutions, and governance, endogenizing one after another aspect of social and political life. In both directions, development economics has overshot the mark - exogenizing law and governance in the name of robust analytics to the point of abstract sterility, only to endogenize law and institutions so indiscriminately that a general call for 'good law', 'strong entitlements', and 'human rights' stifles the ability to make choices and establish priorities.

Such patterns of interaction between disciplines are not only the unfolding of a logic, a pendulum between robust exogenizing models and context-specific embrace of institutions. Relations between more or less dominant professional disciplines are also matters of reciprocal influence and competition. It would be interesting to know what norms or entitlements structure the relationship between economic common sense (a disciplinary 'centre') and common sense about law, governance, and institutions, which has always been more peripheral to development policy. Some of this may be a function of institutional authority, professional resources and prestige, and the intellectual path-dependence of policy elites. Some may be a matter of ideas. It may be, for example, that a shared commitment to the instrumental nature of law might distribute authority asymmetrically between economic ends and legal means. A commitment by both disciplines to avoid seeing legal arrangements as a terrain for political contestation and choice might have kept law peripheral even when economists embrace good governance, formal property entitlements, or human rights as the very definition of development. Needless to say, these remain hypotheses. The suggestion is that the diverse knowledge practices of experts may also be understood as centres and peripheries in a field, their relations driven by professional ambitions, desires to affiliate and disaffiliate, dominate and submit, and structured by status hierarchies, institutional arrangements and habits of reciprocal persuasiveness or impenetrability that function in ways analogous to the role of entitlements shaping bargaining powers in the political and economic life.

It is not only that symbolic systems have centres and peripheries. The 'centres' and 'peripheries' in economic, political, or legal systems may also be symbolic or allegorical. As such, they need to be inhabited or performed, and the effect of such a performance is not certain. Indeed, we might think of domination or hegemony as a performance or assertion of centrality - or an ascription of peripherality - which gives rise, in a significant audience, to the effect of centrality or peripherality. In law, it has become routine to assess assertions of jurisdiction for their effectiveness. The extraterritorial effect of national jurisdiction is a function of the willingness to assert it and the ability to generate cooperation or acquiescence in its exercise. 
International lawyers are accustomed to speaking about the authority of norms as a matter of their persuasive effect, the legality of political activity as a function of the legitimacy with which it is viewed by the international community, its legitimacy a function, in turn, of its perceived legality. It is odd that this way of imagining legal powers and obligations has so rarely given rise to analyses of the relative persuasiveness or legitimacy of performances from divergent quarters. And yet it seems undeniable that legitimacy and persuasiveness can be both cause and effect of being 'the centre'. When the United States makes an assertion to its European allies that the power it wields in one or another disputed context is the exercise of right, what is at stake is not only the one-off legitimacy of the act or persuasiveness of the claim, but also the relative position of European and American authorities in a norm-drenched political system. To say that international law is a 'game of the middle powers' is to say that European nations more readily find themselves occupying the symbolic centre of the global legal order than of the global military or even economic system. Their normative assertions persuade, their action - or inaction - seems legitimate.

Why would this be interesting? For Myrdal the goal was improved policy - what can be done, where are the levers, how can economic analysis be mobilized by planners to encourage upward trends and discourage downward spirals? He imagines a site where these things could be understood and encouraged or contravened - the planning agency, the public hand. And indeed, if you are a policy planner, this kind of sceptical, middle-level analytic can be particularly useful. No big story, just an orientation to the kinds of things that might play out among social and economic aggregates and suggestions for dynamics to help or hinder.

At the global level, few scholars today write with this much faith in the availability of a public policy hand. Centre-periphery analytics are deployed more often to criticize than to focus policy proposals. The impetus is less reform than diagnosis, to raise awareness of contestation in the warp and woof of the quotidian. Centreperiphery analytics are useful in critical endeavours precisely because they reframe disciplines grown comfortable with constitutional stability and modest reform to focus on the reproduction of asymmetric power.

Criticism is a rhetorical business. The centre and the periphery are positions that must be claimed, denied, asserted, or attributed. It is them and us - and we, we are the periphery! (Or, anyway, it is we who affirm their marginality and represent their interests.) The danger here is the tendency to overstate. Analysis of the relationship between a centre and a periphery seems most effective as criticism when the centre and periphery are hard-wired by history, when the centre has all the stuff, exercises all the power, reproduces the hierarchy. The gold standard for criticism, in this sense, is the iron cage. Where the whole arrangement is loose and unstable, or the results just a lucky - or unlucky - coincidence, the critical sting seems less potent. It might actually be an iron cage, of course. But maybe not. Things can go poorly even when the periphery captures the spoils, inheriting the moral pleasures of marginality, or relief from the burdens of rulership. Indeed, the most interesting hierarchies, the most obdurate dominations, can arise where power does not simply flow downhill from centre to periphery. Nor is there a persuasive model or compelling analytic 
reason for thinking that centres will always oppress peripheries. Sometimes there are virtuous cycles and all boats do rise.

Critical claims to peripherality and allegations of centrality must overcome the background complacency which comes from thinking there is no system - or everyone is, in some sense, on the same footing. It no longer seems that the 'system' has a 'logic' any more than that history marches to a dialectic. Much is coincidence. Often there are unanticipated disturbances, external shocks, puzzling reversals, and creative reinventions. To claim that this is peripheral to that requires a suspension of awareness of life's complexity, irrationality, and unpredictability. Even then, it can be difficult to tell just who is the centre and who is the periphery. There are centres in the periphery, peripheries in the centre. More importantly, perhaps, centres can feel peripheral, style themselves marginal, bemoan their distance from power. And in every family we can identify the peripheral drama queens around whose instability and weakness the entire family rotates. In the end, centre-periphery analytics are both interpretations - this is how things are - and, when the interpretation holds, persuades, reconfigures the situation, interventions. To call out the perpetual drama queen victim on his centrality is to name and to shame, whether the ostensible victim is an adolescent or a nation.

Centre-periphery analytics provide a framework for criticizing the status quo by asserting the presence of a power and a hierarchy that is otherwise denied. To the extent the political and economic world has come to be managed by experts, the hierarchies and power dynamics of contemporary life are often denied by the routine sensibility, belief system, and practices of expert professions. Centre-periphery analytics can also be useful in scrutinizing the complacency of an intellectual discipline or professional sensibility, most powerfully by articulating a scandal in a profession's relationship to power, uncovering a profession's implication in producing hierarchies it either denies exist or claims to be subverting.

This can often happen when a field is confident it has inequality under control either because it is not bothered by the inequality or believes it offers a remedy. For example, it would not have been a particularly trenchant critique of those who built the colonial system to demonstrate that it spawned hierarchies between centres and peripheries - that was the whole point of the operation. Exposure of a dynamic inequality between the imperial centre and the colonial periphery might have scandalized those who believed it was all done from noblesse oblige or as the expression of humanitarian and religious motive, but even they probably understood what was going on - that was precisely why their own good ministrations were needed. It would be a scandal, however, if those ministrations were part of the mechanism by which the dynamic inequality between the imperial centre and colonial periphery were heightened or reproduced. Where the presence of humanitarian actors and a religious justification can be shown in fact to have been a link in the socioeconomic process by which the centre exploited the periphery, you have a scandal.

For international law, colonialism is not a scandal so long as the discipline can say, 'obviously colonialism was terrible, but we got rid of it and are working to undo its legacy'. Nor is it a scandal to demonstrate that international doctrines articulated then or now were unrealistic - the native populations were not really treated as 
equally 'human' and sovereigns are not really 'equal'. International lawyers, then as now, know this. That's what they are against. That is the reason to separate the good, if imaginary, world of international law from the bad world of international politics, and for redoubling efforts to bring about the progressive civilization of those politics by law. It is a scandal, however, if it turns out international-law doctrines proclaiming the humanity of indigenous peoples or the equality of sovereigns as they are applied are in fact part of the machinery by which the slaughter of indigenous peoples was justified or the inequality of nations has been sustained. Antony Anghie makes just such a claim about international law from the sixteenth to the twentieth centuries: humanist doctrines, doctrines of positive equality, institutions of affirmative development, have all in fact functioned to sustain and heighten global inequality. ${ }^{4}$ To the extent the inequality of centre and periphery in the world system is structural, international law is part of the structure. When international law turns out to be colonialism by another name - the name 'self-determination' - we have scandal, for self-determination is just what the discipline felt it had to offer as a remedy.

Recent work on European law is also harnessing centre-periphery analytics to criticize the dominant professional consciousness of European law professionals. For professional Europeanists, it is not scandalous to hear that despite the 'single market', European national economies and regions remain unequal and distinct. They know that. The whole point of extending the four economic freedoms and of the 'cohesion' and 'structural' fund-transfer payment systems - is to ensure that through integration economic growth is possible throughout the Union. The EU project is all about linking centres and peripheries to equalize and grow. As a result, it does pose a critical challenge to the European law field to show that the general legal principles - like 'free movement' or 'social considerations' - at the core of the endeavour are applied in ways which heighten the inequality between the economies of the European centre and periphery. ${ }^{5}$ The devil here is in the details - in the precise ways that universal principles turn out to have diverse meanings and get applied in ways that contribute to dualism. Or in the specific ways a universal programme designed to equalize relations across the EU turns out to accentuate the distance between the centre and periphery. For example, if the structural and cohesion funds effected a net transfer from a periphery to a centre, or if general policies adopted in the name of 'democratization', 'rule of law', or 'economic development' aiming to bring the periphery into harmony with the centre had the effect, at the periphery, of undermining parliamentary democracy, encouraging deindustrialization, strengthening the security state, and the like, there would be

\footnotetext{
A. Anghie, Imperialism, Sovereignty and the Making of International Law (2007) (arguing generally that while international law saw itself as preoccupied with extending a universal normative order to ever more sovereign equals, it was actually preoccupied with managing the dynamics between unequal civilizations or cultures). Damjan Kukovec's ongoing doctoral work argues precisely this. See Damjan Kukovec, 'Whose Social Europe?', talk delivered at Harvard Law School (I6 April, 20Io), available at www.harvardiglp.org/ new-thinking-new-writing/whose-social-europe-the-lavalviking-judements-and-the-prosperity-gap; Damjan Kukovec, 'A Critique of the Rhetoric of Common Interest in the EU Legal Discourse', talk delivered at Harvard Law School (I 3 April 20I 2), available at www.harvardiglp.org/new-thinking-new-writing/a-critiqueof-rhetoric; and Damjan Kukovec, 'A Critique of the Rhetoric of Common Interest in the EU Legal Discourse', SJD dissertation, Harvard Law School, forthcoming.
} 
a scandal. ${ }^{6}$ In each of these cases, the villain is not the centre - it is the glue of entitlement that sets up an asymmetric and disempowering dynamic and the cloak of self-narration that covers it up.

\section{INTERNATIONAL LAW AND POLITICAL ECONOMY}

International lawyers and legal scholars have much to contribute to understanding and transforming global political economy. Heterogeneous strands within the discipline have helped prepare the way for a more sustained focus on the role of law in structuring relations among actors in the centre and in the periphery of the world economic and political system. Unfortunately, the mainstream international legal academy has moved ever further from tackling such large-scale questions. It is important to understand both how the discipline has insulated itself from political economic engagement and what existing critical traditions could contribute to turning things around.

\section{4.r. Why is it so difficult for a field devoted to the law of the international system to address issues of global political economy?}

Since modern 'international law' emerged as a practical and scholarly profession more than a century ago, it has aimed to civilize international politics with the balm of normative regularity and rational dispute resolution rather than diagnose and transform the political economy of the world. In moments of crisis - most dramatically in the years after the First World War - some in the discipline have offered international law as a terrain for renovating cultural and political life, but such moments are rare. More often, international lawyers have taken the structure of economic life as understood by economists and the structure of political life as understood by diplomats at a given moment for granted. Over the last few decades, the internationalization of every technical legal field - and the technical specialization of international legal arrangements - has kept the legal profession from considering grand questions about the role of law in the world's political and economic organization.

The theoretical issues that move the field have always been small-bore adjustments or reassessments of existing institutional arrangements - and of law's own status in a world of political facts and economic forces one simply had to accept. Just how and why and when do norms bind? Might stable behaviour be reinterpreted as constitutionally compliant? Might existing transnational legislative, administrative, and adjudicative processes be adjusted to be more transparent or effective? Nevertheless, a generation ago, the best comparative and public international lawyers were worldly and cosmopolitan, their disinterest in the parochial details of any

Ermal Frasheri makes this point in 'Transformation and Social Change: Legal Reform in the Modernization Process', Nellco Legal Scholarship Repository, 9-5-2008; and in his ongoing doctoral work: 'Of Knights and Squires: European Union and the Modernization of Albania', SJD dissertation, Harvard Law School, forthcoming. 
nation's legal arrangements making them lonely figures in law faculties which were everywhere linked to national political institutions and cultural traditions.

In recent years, the relevance of a specifically international legal field has become harder to see as every national regulatory or private law subject matter has been touched by international or foreign developments. Suddenly, everyone in the legal academy is an internationalist - but none have the brief to analyse law's role in the world system. Their remit is focused on transnational dimensions of their own field. In Europe, legal scholars in every field have become Europeanists, while American law professors, from family law to intellectual property, have become expert in the impact of their regime on the world and of the world on their regime. National regulatory subjects which particularly seem to implicate global economic life have blossomed as fields of their own - international banking and finance, international or comparative antitrust, international taxation, and the like. Perhaps most strikingly, even American constitutional law, that most isolated of academic cargo cults, has become newly focused on the foreign-affairs power, on compliance with international norms, on war powers and the regulation of war, and even on the comparative study of systems thought loosely analogous - Canada, Australia, South Africa, Israel, or the United Kingdom. As a result, the study of international legal phenomena has become linked to the ups and downs of national legal projects of public order, regulation, or private law enforcement. The issues are technical, the perspective pragmatic problem solving. International legal study has become a fragmented reflection of national policy concerns, as if becoming an international lawyer meant becoming an internationalized American or European lawyer, rather than someone able to navigate a global legal order infiltrated by the transnational extensions of multiple national legal arrangements but with its own political and economic coherence.

At the same time, the international-law field has itself responded to the multiplication and dispersion of legal authorities with global reach by repeatedly splitting into ever more technical subfields, each with its own favourite institutional regime and preferred disciplinary interlocutors. In some sense, modern international law was split at the root. The field came of age in the late nineteenth century by repeated division: 'public international law' from 'private international law', the 'law of war' from the 'law of peace', the 'law in war' from the 'law of war', and so on. Although the distinctions did not remain particularly sharp or formal, the process of division continued through the twentieth century. An early and significant disciplinary divisionpublic international law spawning international economic law - bore witness to a moment in which politics and economics were comfortably separate.

In the process, public international law became one specialized field among many, oriented to baseline rules about sources of law, the procedures and institutions of inter-state diplomacy, and those substantive matters which had become the topic of multilateral rule making - but not to the role of law in the large dramas of global political and economic affairs. Instead, international law was preoccupied with its own status as law in a political world - a concern it translated into endless rumination on its 'binding' quality and the machinery of its 'enforcement'. This theoretical focus translated into a doctrinal obsession with sources of law and the 
procedures for making claims, settling disputes, enforcing law, and holding states 'responsible'. The field's substantive energy focused only on domains which had explicitly been the subject of binding international rules, from the environment and human rights to the use of force and the regulation of armed conflict. Assessing the substantive impact of international law on the world political and economic order meant measuring the impact of these positive norms. International law was implicated in the protection and despoliation of the global environment to the extent the Kyoto Protocol applied and was enforced, full stop.

Although the field may at first have seemed foundational - both the base upon which all other international legal fields would be built and the legal foundation for global political activity - public international law soon developed a distinctive perspective and a far more limited domain of interest and engagement. This encouraged the claims by other international legal fields that they were at least as foundational to global legal order, if not more so. In the process any sense of the international system's political specificity was diluted.

In the middle of the last century, it might have seemed the field had discovered a path to renewal. International law's big mid-twentieth-century ideas - transnational law, policy science, functionalism - framed a sociological inquiry into the operations of law in the world and opened the door to a disaggregated and legalized conception of the 'global policy process'. The unfortunate result was a reinterpretation of transnational political and economic activity in legal and increasingly technocratic terms. The functional dispersion of 'regulatory', 'administrative' and 'dispute resolution' capacities spawned a wave of new scholarship seeking the effect of international law wherever two are gathered in its name, dulling the professional experience of a distinctive global framework linked to a global political or economic system. Although ostensibly close to the diplomatic worlds of international organizations and adjudication, its interdisciplinary reference points drawn from political science, international relations, and diplomatic history, its mission bringing law to the world of inter-state power, the public international-law field drifted ever further from focus on the political choices and distributional consequences of legal arrangements. As public international law embraced the fragmentation of the international legal field, law became a way to speak about politics and politics a way to assert legal entitlements. Along the way, the aspiration to offer a distinctive global perspective on the structure of the world political system withered and the experience of conflict, decision, and responsibility were leeched out of our disciplinary images of global order.

At the same time, the field's substantive preoccupations became ever more specific and idiosyncratic. The field promised that law would become the vernacular of legitimacy as legitimacy became the currency of power - and we got a proliferation of international tribunals focused on Africa, an intensification of public naming and shaming rearticulating the division between civilized and barbaric, and a defence of everything from bombing and regime change to life without parole in the language of human rights. A steady focus on 'crisis' and 'transition' and 'intervention' has made it ever more difficult to pose questions about law's role in the quotidian structures of conflict and distribution embedded in the economic and cultural global 
order. Rather than people taking responsibility for decisions, international lawyers imagine a drifting gauze of judicial networks and diffuse stakeholder conversations among a disembodied 'international community' about what it might be legitimate to do about this or that unfolding crisis.

Meanwhile, 'international economic law' and a rejuvenated 'private international law' split off to become fields of their own. Leaving general inquiry into public order behind, international economic law focused on supporting the integration of a global market through the national and international regimes regulating trade. The interdisciplinary reference point shifted from international politics to economics, but not in a way which encouraged focus on law as a link between centre and periphery or as a distributive tool - rather the opposite. A set of ideas about the economics of trade provided an orientation for institutional and doctrinal efforts to harness national regulatory machinery to the expansion of global markets and the erosion of national or local political ambitions to challenge their distributional impact. 'Private international law' focused on the transnational effect of private rights and the procedures of transnational commercial arbitration. Private entitlements are a crucial arena for investigation of the links which bind centres to peripheries and structure global political economy. Unfortunately, the field assiduously avoided such questions, imagining the transnational private legal order as a space outside 'public policy'.

An international law responsive to the political economy of the world will need to escape the grip of these divergent professional styles. International lawyers will need to cross-train, learn about economics and relearn politics as a quotidian matter of hard decisions rather than an intermittent matter of diffuse conversation. The governance challenge is not to bring political actors into law - they are already there. Nor is it to establish - and then work to complete - functional equivalents for familiar national governmental institutions. Projects of functional equivalencean international criminal law, an international administrative law, an international constitutional law, an international judiciary - are notoriously limited in their ability to grasp the global order whole, tending rather toward an infinite ritual of 'progressive development', their completion an ever-receding horizon, their form an abstraction far removed from the national legal and political realities they were established to imitate. Conceived as general global competences, they act in the world as narrow site-specific interventions. None are oriented to the challenge of establishing a public hand capable of taking decisions about the distribution of economic growth. Whether done locally, regionally, nationally, or transnationally, this will require new ways of thinking, new modes of professional expertise, and new uses for old institutions.

At the same time, international economic lawyers will need to relearn the significance of political choice and the dynamic social, political, and economic impact of alternative institutional and regulatory arrangements. The economic target is no longer the efficient allocation of existing resources under constraint or the maximization of comparative advantage. The economic challenge is to understand and make the political, institutional, and social choices to place the global economy on one rather than another growth trajectory. An institutional interface to 
accommodate divergent national conceptions of the regulatory background for 'normal' market activity is not enough. At stake are less the global gains from trade than the distribution of those gains, the bargaining powers through which those distributions occur, and the dynamic social and political consequences of the alternative distributions which come with different economic trajectories. In the same spirit, private international law will need to focus on the role of private-law forms and relationships as actors in the distribution of economic and political powers.

In short, to analyse and engage with the political economy of the world, international law will need to abandon many of its most significant twentieth-century programmatic preoccupations, methodological accomplishments, and disciplinary boundaries. To grasp international law's political-economic significance as a constituter of centres and peripheries or a link and channel between them, the debris of the traditional Westphalian narrative and its twentieth-century modernizations will need to be hauled away. Over the last few decades, a variety of critical and alternative strands of scholarship within the international legal field have pushed in these directions.

\subsection{What heterogeneous and critical traditions within the field have already accomplished to turn things around}

The most important legacy of critical work in the field over the last decades may simply have been to identify the very limited imagination of the international legal establishment and to trace the routines by which it reproduces those limits in the name of transcending them. That work may help open the door to a more broadranging engagement with law as a site for ongoing political and economic struggle. To get there, international lawyers will need to set aside the false promises the field makes about its own significance and potential function in international society.

Many look to international law for the expression of universal values, most commonly in the human rights canon. Critical traditions within the field have stressed the narrow specificity of international law's purportedly universal vision in a world where people disagree about the most fundamental things and where values are not, in fact, universal. Projects to pursue particular ends in the name of universal values run into characteristic difficulties and generate predictable blind spots among those who pursue them. Human rights, a very specific late twentiethcentury endeavour, is no exception. Human rights can as often be part of the problem as of the solution. The proliferation of 'rights' is not only a way to speak truth to power. Power also routinely asserts itself as right - perhaps particularly as the expression of human rights.

International law also promises to identify the legitimate actors in the international system and their powers - most formally by enumerating the 'rights and duties of states'. This is partly sociological-simply registering the powerful and their capacities. And of course it is also normative - offering a measure of the legitimate uses and misuses of power which may be useful in resolving disputes about who can do what. In fact, the field is neither describing the world as it is nor helping us to imagine and construct a world that could be. Indeed, the field's universalist descriptions of actors and structures more often occlude the way power flows through the capillaries 
and commanding heights of global society. Nor is the discipline's fantasy-land of institutions and regimes - an international community of stakeholders, a global society of rights-bearing individuals, a universal international criminal law, a transparent international administrative law - a plausible programme of action. These are the programmatic fashions of particular transnational elites, reassuring distractions from understanding how the world is put together and how it might be changed.

Perhaps most importantly, international law promises a catalogue of policy tools and institutional arrangements with which to confront global problems. International lawyers have long said that like the European Union, only more so, the international order governs in the key of law rather than that of budgets or a monopoly of force. It is no longer surprising to find in one after another area that international law's most coveted projects and proposals are wildly inadequate to the tasks they purport to address. Their architects are embedded in the machinery of global political and economic power responsible for the difficulties in the first place. That their best efforts in response would be limited by fealty to the limits imposed by that machinery is to be expected. Nevertheless, for whatever reason, the International Criminal Court could triple its budget and jurisdiction, the United Nations could redouble its peacekeeping efforts, the international human rights community could perfect its machinery of reporting and shaming - and it would not prevent the outbreak of genocide, the collapse or abuse of state authority. Every American and European corporation could adopt standards of corporate responsibility, every First World consumer could be on the lookout for products which are fairly traded and sustainably produced, and it would not stop the human and environmental ravages of an unsustainable global economic order. America could sign the Kyoto Protocol, could agree with China and India and the Europeans on various measures left on the table at Copenhagen, and it would not be enough to prevent global warming. The United Nations' Millenium Development Goals could be implemented and it would not heal the rupture between leading and lagging sectors, cultures, classes. The Security Council could be reformed to reflect the great powers of the twenty-first, rather than the twentieth, century, but it would be scarcely more effective as a guarantor of international peace and security. Global administrative action could be everywhere transparent and accountable without rendering it politically responsible.

Each of these efforts might be salutary. Some may be terribly important. At best, however, the implementation of these schemes would kick things down the road, manage expectations, render the problems to which they are purportedly being addressed sustainable and thereby reaffirm the current distribution of powers and the centrality of the centre. As a result, completing the programme of international law would not renew the political economy of the world - any more than finally 'completing' the European Union would resolve the dynamics of dualism which have rocked the project from Brussels and Frankfurt on down. The project of continuing the project is part of how those dynamics are sustained. In Europe, a permanent transition toward an ever-receding goal of a 'political' union sustains the technocratic separation of economic and political imperatives - and reinforces the divide between leading and lagging regions. Globally, the permanent transition toward a universal 
legal order of equal sovereigns sustains one after another project of hegemony. As a result, rather than a toolkit of policy solutions which might be adopted in the global public interest, it would be more accurate to see international law as a continuation of the politics of war and economic struggle, as a legitimating distraction from the effort to remake those politics or reframe that struggle, and as an effort to institutionalize the ideology of a particular time and place as universal.

Only after pushing past international law's classic self-conception - as the highest expression of universal values, the best map of the world's political actors and their powers, and toolkit of policy solutions - will international lawyers be able to use international legal materials to illuminate the global political and economic process. A crucial first step is to change the profession's default perception of the distance between legal and political arrangements. Although international law has long sought to throw a fragile net of rules across the roiling waves of global politics, its relationship to power is a far more intimate one. Critical traditions focus on law as the language in which governance-even war-is written and performed. But this has not civilized global politics into a legal 'order'. Political struggle continues in and through the regimes and vernaculars of international law. The global political/legal system remains an extremely disorderly, plural, and uncertain one in which international legality is less a matter of either normative validity or persuasion than it is a form of effective assertion or performance of authority. When international lawyers say that compliance with international law legitimates, whether on the battlefield or off, they mean that grinding poverty, terrible inequality, environmental destruction, and the premeditated destruction and death of war have become acceptable. It would be more accurate to count the vernaculars of legitimacy and the cramped channels of public order entrenched by international law among the root causes for the difficulties facing the world.

This way of thinking opens the door to rethinking international law as a terrain for political engagement rather than as a normative or technical substitute for political choice. In a similar way, it should be possible to shrink the experience of distance between international law and the routine operations of the economy. International law has long been rather unconcerned with economic affairs. Economics either happens elsewhere on a different scale - within the nation - or is the domain of other legal disciplines, most prominently 'international economic law'. I see this routinely among students aspiring to work in the field of human rights, on the one hand, and those aiming to contribute to the management of the global economy or to national economic development, on the other. Too often, the first group is uninterested in economics, except to the extent social or economic development objectives might be the happy consequence of human rights enforcement. The latter are unconcerned about international public law other than the few institutions marked out as part of the global economic order, the World Trade Organization in particular.

Critical strands within the field have aimed to unravel public international law's economic innocence. The structures of authority articulated in public international law - first among them territorial sovereignty - and the institutional separation of public and private powers ratified by the field are crucial in setting the background conditions for both national economies and global economic activity. At the same 
time, the disciplinary claim by 'international economic law' to be the law behind global economic activity is wildly inaccurate. International economic law is a far narrower institutional and normative project focused on the relationship between national regulatory structures affecting trade. The law behind global economic activity is much broader - a vast and very uneven affair. Private law here, local regulations there, informal industry standards in this sector, public administrative regulation in that sector, habits of jurisdictional assertion and forbearance, internal corporate policies and the customary norms of illegal and shadow markets are all part of the story.

As the profession's picture of the laws structuring global political and economic life expands, it becomes ever more obvious that they are anything but distinct. Just as it becomes clear that the law of the economy is a space of political choice and struggle, or that the legalization of political life has structured the distribution of economic opportunity and reward. It is in this sense that critical work has proposed to think of private law and corporate governance as part of the constitutional infrastructure of global governance, and private obligations as background limits on public power. Think of the network of obligations which tied our global financial system in knots - collateralized debt obligations, credit default swaps, and securitization so complex and markets so rapid no regulatory authority can unravel them. Or corporate governance so fluid and inscrutable one rarely knows who calls the shots. All these stand in a long line of private arrangements - including slavery made in one place that restrict public policy alternatives elsewhere.

Taken together, these critical efforts aim to reframe international law both to expand the range of normative and institutional material to be considered when contemplating the world's legal regime and to break the habit of thinking of international law as distinct from politics and economics. In some sense, of course, this is not new. The world's political and economic elites have long learned to inhabit a fluid policy process in which they as often make as follow the law. If international lawyers now draw the consequences of that knowledge as scholars, they will be more likely to remember that things they do not like are also legal institutions and structures of governance: poverty, war, inequality. Only by abandoning the comforting idea that 'international environmental law' concerns only environmental protection and remembering that law also comforts those who would cut down the forest can the profession come to explore the role of law in the reproduction of poverty or the continuity of war in peacetime.

These critical reinterpretations open the door to treating international law as a political-economic space by displacing the field's self-conception and identifying a wider range of materials which might serve as sinews of connection distributing political or economic power among centres and peripheries of the world system. To the extent critical voices are prone to think the global political order is dominated by statesmen and politicians from a hegemonic centre - or that the economy is directed by 'investors' and 'multinationals' pulling the strings from some Davosinspired eyrie - an expanded conception of the legal terrain across which political and economic forces contend can serve as a useful corrective. The political economy of the world is a more diffuse, dynamic, and multi-directional system. The process by 
which authority, opportunity, and reward are distributed among people operating in that system is far more difficult to decipher.

This is particularly the case to the extent the sinews binding the political economic system together are less norms enforced by institutions than ideas diffused across the world about who is entitled to what. Heterogeneous strands in the internationallaw field have also explored international law as a set of ideas, a mental map of the world, a set of beliefs about legitimate and illegitimate action, a form of technical or professional expertise. It is difficult to understand how knowledge about the world distributes power between centres and peripheries, how it encourages or enables some actors to extract political and economic rents from others. A first step is simply to understand more fully how a field of knowledge like international law operates as a pattern of authority.

It is clear that the shared vernaculars of professional experts can influence what individual and institutional actors believe they ought and ought not to be doing. After all, if for a generation everyone thinks an economy is a national input-output system to be managed, and then suddenly they all become convinced that an economy is a global market for the allocation of resources to their most productive use through the efficiency of exchange in the shadow of a price system, much has changed. That is also governance. Indeed, to the extent expertise has become the global currency of rulership, understanding the political economy of the policy expertise system has become a crucial part of understanding how we are governed. A better map of the intellectual and institutional system of rulership-by-expertise may open up new opportunities for innovative policy and political contestation.

For example, it is important to recognize that the profession's insistence that international law has domesticated the pre-Westphalian world of empire, religious strife, and war by rendering religious confession and ideological conviction matters of domestic concern and harnessing violence to the enforcement of right, while comforting, is not accurate. Global governance remains as much a matter of religion, ideology, and war as of persuasive interaction among the elites we call the 'international community' about what is legitimate. In fact, the informal and clandestine, the sacred, the violent, and the spectacular are part of how the world is governed. The disciplinary urge to push them off-screen, either back in history or below the waterline of sovereignty, nevertheless has a powerful impact. People who see themselves as religious actors on the global stage have a hard time seeing themselves reflected in the vernaculars of authority through which that stage is built. People who work in institutions which pride themselves on their centrality to global political and economic order have a correspondingly hard time figuring out how to think about religion other than as a matter of personal belief or local culture. It would not be surprising to find that these ideas about religiosity helped distribute the experience of authority to act in the political economy of the world in various ways.

It is difficult to develop a satisfying picture of the ways in which the focal points, blind spots, and biases of expertise help to construct relations between centres and peripheries. More often, scholars focus on the authority of agents they can see to act within structures they understand. Legal scholars have paid too little attention to the myriad ways power flows through common sense, affiliation, or the experience 
of victimization, pride, and shame. All these things move like a virus or a fad, but the discipline's epidemiology is weak, the sociology of status, convention, and emulation at the global level rudimentary. Indeed, to trace the contours of global governance is to follow the hand of knowledge in arrangements of power. Doing so would help to reframe international law less as a box of tools, a catalogue of actors, a catalogue of universal values than as the articulation of a shared world.

There is a long way to go to understand how our world is made through articulation and assertion, how the practice of assertion is structured by institutional and professional technologies, and how these, taken together, distribute opportunity and authority. Forty years ago it was common to say that the most significant product of the space race was a distant photo of planet Earth - and there was something profound in the observation. Such things constitute a world long before scholars begin to identify actors or structures, assert rulership, or solve problems. Of course, such ideas arise from somewhere. Without a space programme, perhaps without a Cold War, without Life magazine, we might not have had those photos at that moment in that way, and the idea might have arisen differently, at a different moment, or have seemed less compelling. The disciplinary practices of experts are part of the technology through which the world to be governed - a world of centres and peripheries - is assembled.

The role of knowledge in global power is particularly easy to see because global governance is so often an assertion, an argument, a programme of action, or a call to resistance. Indeed, when it comes to global governance, saying it is so can make it so. Or, perhaps better, saying it is so is often all there is to it. This is always true of public authority - it comes into being and functions as an assertion. In other contexts we have got used to this. People forget, other than in moments of revolutionary turmoil, that the sovereign is just a person who says he is king. The institutionalization of public power makes authority seem 'real', the distinction between 'public' and 'private' natural. In global governance, the saying and performing are right on the surface. Global governance must be claimed, through an assertion that this or that military deployment or human rights denunciation is the act of the global public hand - the 'international community' in action. The rhetorical dimension of global power is equally significant for those who would resist. Saying it is not so is rarely enough to unravel the world's structure. Nevertheless, identifying the global hand in local unpleasantness is also an assertion - and an allegation of responsibility. Whether one aspires to bring global governance into being or fears its power, one must name it, assert it, and identify it, before it becomes something to build or destroy. Indeed, in a sense, 'global governance' is simply the sum of what those who wish to manage and to resist globally have jointly drawn to our attention as governance.

One way in to this set of issues may be to explore further the way in which international law is performed as an argument about international law itself - its limits and its potential. Modest differences between policy proposals are routinely debated as if the very possibility of legality were at stake. This tendency is common in discussions about global governance. The 'international community' discusses intervention - whether in Libya or Syria or Sudan - in a way which focuses as much on its own credibility and authority as on the local consequences of one or another 
course of action. At stake in debates about economic stimulus or austerity plans is not only or even primarily who gets what, but rather the 'credibility' and 'stability' of the regime itself - the euro, the EU, the market. And this kind of association can be self-fulfilling. If everyone thinks the stability of the euro is at stake, then - well, the stability of the euro is at stake. In this sense, the constitution of a world is ongoing, a technical and institutional practice as well as a communicative and performative work of the imagination.

\subsection{Implicating international law in the relations between centres and peripheries}

Understanding the world-making effects of the knowledge practices of rulership is an enormous programme for thought. International legal scholars could contribute by situating international law in the larger global political and economic system, interpreting its role as the glue linking leading and lagging ideas, regions, or economic sectors, or as the cloak hiding asymmetric dynamics of power in the political economy of the world. Conventionally, the field articulates a universal and homogeneous world from which it stands somewhat apart. There are inequalities, of course, but the world it sees - and it would make - is a far more equal one. To reframe the world that international law conjures into being as a system of centres and peripheries would already begin to articulate a quite different place.

To reinterpret international law as the language constituting centres and peripheries in the world's political and economic system would certainly transform the discipline's self-image. As it sees itself, international law is the handmaiden, the gentle civilizer, the voice crying out in the wilderness, articulating valid norms, naming and shaming from the sidelines. Its kingdom lies in the future, present now only as a promise. International lawyers can find it absurd to be treated as 'the centre' of anything. Don't we see how hard they are struggling just to stay in the game at all? Why stigmatize them, for crying out loud, when there are so many bigger fish to fry?

To critique the rulership of international law, you must establish it. Implicate this field in this order - constituting actors, channelling interactions, validating or emboldening reciprocal claims. Nail down the role of international legal doctrine, legal professionals, legal institutions, and structures in governance. Who navigates by their maps? For whom is international law the language of social or political enforcement? What bureaucracies have been spawned in their image? Who is thrust aside, who canonized as the apex of the international community? There has always been something paradoxical here - the discipline also insists (if in a different voice) that its norms are effective, enforced, important. The odd thing is that establishing the rulership of international law can nevertheless be a scandal.

The critical point is that the field governs differently - and for different interests than it imagines. International law feels that it governs from the periphery-that states make the norms and enforce them. That power lies with politics. Those working in a more critical vein have proposed something different - first, that international law is a centre which exercises power in the old-fashioned hierarchical sense: human rights as governance, governance feminism, international law forged in and facilitating 
the colonial encounter. Second, that international law has been the stage on which projects of centrality and marginality have been staged. Arnulf Becker, for example, has traced this theatre in the efforts of intellectuals from the semi-periphery to build international law in the centre as they simultaneously pursued political projects of the periphery in what they took to be the world's cultural, political, and economic order.7 International law frames a hub-and-spoke world between the developed North Atlantic industrial democracies and everyone else when it consigns the second to the law of 'co-existence' or the cold winds of free trade, while embracing the former as an advanced space for regional integration and industrial policy, for the law of 'co-operation' and the dense fabric of collaboration characteristic of relations among liberal democracies. ${ }^{8}$ In all these ways, international law offers a normative vocabulary of entitlements that constitutes and structures relations among actors, interests, and ideas in ways which leave some at the periphery and honours others as central. It is the glue.

International law also constructs a world when its votaries imagine international law as an artificial construct atop the real world of politics among nation-states; or when they imagine that international law exiled religion to the pre-Westphalian past, pushing confession below the waterline of sovereignty; or when they exile women into the private, the local, the cultural; or place private commercial activity outside the domain of international politics and governance. These ideas generate narratives and institutions and expectations which shift the powers and status of people inhabiting these identities to the periphery. And all the while international law speaks the language of universals, embracing and arrogating to itself the universal ethics of human rights, the criminal power to tell right from wrong, the savvy political calculation by which necessity and proportionality are measured out in war. In doing so, it has also become the cloak.

International legal scholars could do more to understand how this generates asymmetries - between religious and secular, or between the reality of politics and the artificialities of law. Does this have some bearing on the way relations between 'real' states like Israel and artificial 'entities' like the Palestinian National Authority become asymmetric? International law is part of the field, the terrain, the language, the structure, through which asymmetries between secular ethics and religious confession, or the diplomatic world of international relations and the economic world of private markets, arise and are reinforced. It provides the normative fabric, the marker of status, the purveyor of entitlement through which the routine operations of people pursuing politics and economics, ethics and religion, generate asymmetry and hierarchy. The point is less that international law exercises power as the centre than that it makes itself available as a lexicon of entitlement in a field characterized by dynamic asymmetry.

See Arnulf Becker Lorca, Mestizo International Law: A Global Intellectual History, I 850-1950 (forthcoming 2013, Cambridge University Press).

8 See, for example, W. Friedmann, The Changing Structure of International Law (I964); A. Slaughter, 'A Liberal Theory of International Law', Proceedings of the 94th Annual Meeting of the American Society of International Law (2000) 240; and D. Kennedy, 'Turning to Market Democracy: A Tale of Two Architectures', (I992) 32 HILJ 373. 
The potential of centre-periphery analytics for international legal analysis will only be realized if critical scholars can relax the iron-cage top-down pre-Foucauldian model of power so commonly associated with centre-periphery dynamics and learn from international law's own insistence that the world's legal and political order is far more mixed up and fluid than that. Twentieth-century international law was onto something - or created something - when it refigured world order as an open and shifting process whose 'governance' was more a functional reinterpretation of things dispersed across the institutional and political life of the planet than the work of agents empowered by structures. In its own imaginary - and in life international law no longer sits 'on top', governing the relations between states. It prides itself on having become diffused through the global political process as a vernacular of legitimacy, as a horizontal theatre of argument, performance, claims, and assertions. Anti-formalism, anti-foundationalism, and embrace of the dispersed theatrics of global power have all been hard-won in the international legal field. To focus on international law's role in the reproduction of hierarchies of centre and periphery in the world, international lawyers need not turn back from these discoveries. It only remains to develop a centre-periphery analytics every bit as antiformal, anti-foundational and attuned to the dispersed powers of social performance and expectation.

How, for example, does the commercial arbitration regime reinforce the centrality of the North, the private, the economic vis-à-vis a periphery of the South, the public, the political? It is hard to say. The regime looks evenly balanced. States - like companies - sign up. The regime itself could hardly be more dispersed or ad hoc. The developed world is learning that its own regulatory regimes may yet come to be as vulnerable to attack by trading partners as those of the emerging markets whose policy space was meant to be constrained by the discipline of bilateral investment treaties. And yet, somehow commercial arbitration has metastasized to become an adjudicator of last resort for reviewing the legislative, administrative, and even judicial decisions of the developing world. Just how do commercial and financial imbalances translate into political restraint? Could we actually imagine Third World investors using arbitration to contest - and successfully stay - the implementation of a US Supreme Court decision as recently happened to Ecuador in the ongoing Chevron case? If not, what are the legal, professional, ideological, commercial, or political sinews that reproduce this imbalance? As commercial arbitration, in Garth and Dezalay's compelling phrase, goes about 'dealing in virtue', how are hierarchies left in its wake? ${ }^{9}$ The answer will be fine-grain, even if the outcomes are stark.

Centre-periphery analytics might also help us understand the internal economy of a profession for which rulership is both scandal and dream. There is asymmetry and dualism within the self on the terrain where the field's will to power and to marginality are managed, a centre and a periphery in phases of the international legal professional's sensibility and self-image. This internal ambivalence drives

B. Garth and Y. Dezalay, Dealing in Virtue: International Commercial Arbitration and the Construction of a Transnational Legal Order (I 996); see also A. Shalakany, 'Arbitration and the Third World: Bias under the Scepter of Neoliberalism', (2000) 4I HILJ 4I9. 
international lawyers working in the humanitarian field, for example, to oscillate between situational pragmatism and a more ethically self-confident universalism. Perhaps they are pragmatic in the field and ethically self-confident in headquarters, savvy over lunch and sanctimonious in their pitch to donors. Both are part of their professional style. Relations between them are fluid and differ over time and in different institutional settings. It is difficult to understand how these postures fit together in a professional style. Often, however, there is asymmetry, pragmatism the central professional sensibility at the International Committee of the Red Cross, ethical self-confidence at the centre for human rights organizations addressing the same battlefield activity. Relations between these institutions, between the doctrines and priorities embedded in each, in part may be a function of the dynamic between these different professional sensibilities. A further avenue for research: in the shadow of what psycho-social or professional rules do these sensibilities relate to one another? Do these asymmetries arise?

In all such matters of interpretation, perspective matters. Talking about centres and peripheries sounds different at the periphery. Stories about difference and domination which make powerful politics in the centre can also offend-identifying the excluded subjects, the unrepresented stakeholders, pinning victims to their subjugation. How does it sound at the periphery to hear it said that sovereignty is just a 'bundle of rights', or, in the words of the I949 ICJ, 'an institution, an international social function of a psychological character'. ${ }^{\text {Io }}$ Thanks, but we just got here - we'll stick with sovereignty as exclusive political power within a territory. When the EU tells 'new members' how privileged they are to have joined a club of equals, it speaks to their hopes, their dignity. Why should they want to hear that they are still 'the periphery'? A lot depends on how angry the audience is to begin with. Those of us who talked about centre-periphery relations in the Eurozone seemed like spoilsports as the 1992 'internal market' programme took off. Less so now.

I routinely ask my students how they see their generation's project. Is 20 2, I ask, like I648 or I9I9, when it seemed everything needed to be rethought? Or is it like I945, when the international order seemed to need reforming - but not remaking. Tweak the League Covenant and you have the UN. Replace European empire with self-determination under American hegemony and continue. Or is this like I989, when the demand was not reform but implementation - with Communism defeated the solutions put forward a generation before could finally be implemented.

Unsurprisingly, many go for the middle position. Reform, add Brazil to the Security Council, sort out the democracy deficit and currency travails in Europe with another round of treaty drafting. But an ever-increasing number say 2012 is their I648. As we talk it through, it often seems the division reflects, as we say, 'where the students are coming from'. Not necessarily their nationality - but their sensibility. In this sense, the political appetite for criticism has a centre-periphery dynamic of its own. Those who hope to inherit the commanding heights split between I 945 and I989. Those who feel their interests, politics, national projects, have been stymied by

Io Corfu Channel (United Kingdom v. Albania), Merits, Judgment of 9 April I949, [I949] ICJ Rep. 4, at 39 (Judge Alvarez, Individual Opinion). 
forces beyond their control opt for I648. The conviction that the preoccupations of the international legal field pale before the injustice of the world is not a recipe for reform or renewal. It is a recipe for disenchantment, for a withdrawal of confidence, affiliation, interest, from the machinery we know as 'governance'.

Indeed, the plausibility of centre-periphery stories depends on where you stand. At the centre, the system seems far too squishy for there to be a centre-periphery dynamic. At the periphery, the dynamic seems far too obvious for the centre to be squishy. Discussion between these positions is unlikely to be productive - indeed, the difference between them is likely to be exacerbated by dialogue, for each is denying what the other finds most true. Moreover, in some sense both sides err. Just because the order is plastic, the centre squishy, does not mean there is no centre and no periphery. But just because there is does not mean there's an iron cage - or an iron will. It can be unfair and hierarchical and still not be a conspiracy, diabolically difficult to change and still not be necessity.

For the last few years, I have been participating in discussions at Davos on global policy, risks, and governance. Just after the crisis, much seemed up for grabs - the World Economic Forum launched a 'Global Redesign Initiative' to support what they called a 'fundamental reboot' of the 'global architecture'. They were clear, however, that this was not I945- let alone I648. No large institutional reorganization seemed possible - or wise. What was necessary was a new spirit at all levels, and a new willingness to use the tools at hand to respond to urgent issues in new configurations. From this 'centre', global governance was something already constituted global elites could and should undertake - if only they had the will. Will was hard to generate, however, with governance so fragmented, so disparate, so powerless in any particular site.

It looks more like I648 if you feel the world is already governed but you are not part of it. If you can feel that the global economic forces that shake the economy, the society, or your own family are facilitated by someinstitutional or legal arrangements. From this perspective, economic instability or poverty are not problems which escape governance. They are the by-products - or even the intended consequences - of the current governance arrangements. It is easy to conclude the people at Davos must want it to turn out this way and have got what they want.

There is little direct dialogue between these positions. At Davos there were demonstrators and lots of barbed wire - one friend came back through security to the conference hall proud to have collected a couple of rubber bullets. But these perspectives do interact. In recent years, a new vernacular has arisen in governance circles to discuss the interaction between these perspectives. To this way of thinking, the relationship between a centre that realizes it is too squishy to do more than play for time and a periphery outside demanding more should be understood as a matter of social-political risk management and 'sustainability', a term detached from its origins in environmental science. The basic question for rulers: how much time do we have? How long can we kick the can down the road, trying to get things right, before the problem swamps us through the machinery of political or social unrest? Global fiscal imbalances are 'unsustainable', in this sense, for example, if they will lead to political rupture before we can turn them around. Although most 
social institutions are all too sustainable - poverty, inequality, ill health - relations between the centre and the periphery often do seem to implicate the system's own sustainability.

This new ‘sustainability' analysis is a governance vernacular for managing centreperiphery dynamics. It is not demonstrations facing off against bullets, rubber or otherwise. Everyone is also calculating, interpreting, imagining their situation relative to the other and communicating. It is not clear, ultimately, who is 'the centre'. Those on the street can also play the sustainability game - perhaps they will hold on long enough for something to crack. For the rulers, knowing how little can be controlled, it is easy to overestimate the potential for everything to slip out of hand. Moreover, the extent to which the periphery is willing to accept marginalization or exclusion is itself a moving target, shifting, in part, as belief in the plausibility of the narratives of the centre waxes and wanes.

This kind of symbolic system seems ripe for analysis in Myrdalian terms. There is a loose dualism - those outside, those inside; those near and far from some 'centre'. Their relative positions are themselves part of what is at stake in their interactions, each by turn claiming the modesty of the periphery and authority of the centre. The interaction is structured. The positions are constituted by 'entitlements' which rest in law and social expectation. There are avenues of reciprocal influence, tendencies to spiral, whether viciously or virtuously.

I have looked at a number of international doctrinal worlds over the years - most recently the complex duet between humanitarians and military strategists over the legitimacy of war. They all have something of this structure. A loose vernacular between an 'outside' and 'inside' that seems amenable to interpretation in dualist terms, avenues of interaction, patterns of persuasion, all nested in a set of what we might think of as entitlements. The difficulty is to figure out how it will work when you turn it on. Will human rights and humanitarian law civilize the military or be co-opted by them? Can anything be said about how the relative persuasiveness of their positions will develop over time? Increasingly, I believe the answer is yes.

\section{INTERNATIONAL LAWYERS AND THE REMAKING OF WORLD POLITICAL ECONOMY}

Such an analysis may not be politically satisfying. If you are occupying Wall Street or, for that matter, Tahrir Square, the centre-periphery dynamics in international law may seem an astonishingly elite preoccupation. What about real politics! As an Egyptian friend of mine put it: 'Excuse me, but we have a revolution going on.' And revolutions call out for bolder centre-periphery narratives, clearly identifying whom to favour and whom to oppose. The difficulty is that even revolutionaries sometimes lack a strong theory - or even a good sociological picture - of how things hold together. It can be tempting to turn back from a twentieth-century embrace of power as performance and argument and identity to the firmer stuff of interests, structures, classes. Real centres and real peripheries. The critical project I propose leans against this kind of political demand. Centre-periphery relations are far less mechanical than that and better thought of as matters of interpretation and assertion, 
tools for the development of dynamic accounts of mid-level relationships among positions, sectors, regions, or ideas, frameworks for uncovering the distributive work of legal arrangements and expert knowledge practices.

At the same time, for international lawyers to take on the challenge of understanding and transforming the political economy of the world, they will need to turn against professional demands for an account of what international law permits and forbids or how the world is legally constituted. The world simply is not constituted in the sense that things fit together in ways articulated in foundational legal documents. Stories about the UN charter, the WTO, the human rights corpus as world 'constitutions' are fairy tales and international law is far too fluid to serve as a judge of the permitted and prohibited. International law is better understood as part of the glue that holds people, positions, and places in dynamic relations with one another, the sinews that link centres and peripheries, and the cloak that obscures the dynamic operations of hierarchy.

Thinking about 'political economy' has become difficult because politics and economics have been structured to operate on different scales, with different players, served by different professions and interpreted by different academic and expert disciplines. Politics and economics will not be brought together like great powers negotiating a new treaty. Nor will they be brought together by academic theories of their inseparability. They will be reunited by reconfiguring the doctrines, institutions, professional practice, and simple common sense through which they have become separate. This is the point of intellectual and professional cross-training: to disestablish the parallel cadres that service the public and the private, the political and the economic. This is the goal of unravelling the distinctions whose expert interpretation and management confirms the separation - between public law and private law, between market-supporting and market-distorting public policy, and so forth.

For the professional political class to remake the world's political economy, they will need to find new institutional channels to integrate transnational interests and new levers to contest faraway decisions which affect their interests. The global political-economic regime will need to make policy space for alternative national and local experiments and strategies designed to manage the internal distribution of growth between leading and lagging sectors or regions and improve the national capacity to capture gains from trade and structure its own insertion into the global economy. Effective governance is no longer a matter of eliminating the corruption or capture of public authorities - difficult as that is. Nor is it a matter of sound corporate governance, corporate social responsibility and effective regulatory supervision - difficult as those are. Effective governance requires that the public and private actors become adept at something none are now well organized - or well disposed - to attempt: managing the distribution of growth, linking leading and lagging, managing the political economy of dualism. And they must do this not only in their backyard, in their territory, in their sector, but in a new world of shifting relations and linkages. Where small things have large effects, where local rules govern global transactions, and where very little is transparent or predictable. Only by considering economic and political objectives at the same time and on a parallel 
scale will it be possible to respond to the global challenge of linking experimental, leading-edge economic dynamism wherever it occurs with everyone else. Across cities, within and between nations, in regions, across the world.

International lawyers have much to contribute to such a project, particularly if they grasp the depth of injustice in the world today, the urgency of change and the significance of their professional routines in the reproduction of political incapacity. Legal scholars have generated new economic and political ideas before - not all of them sensible. They could do so again. Indeed, the presence of law in the foundations and ongoing practices of both economics and politics makes it surprising that they do not. Nevertheless, a great deal of intellectual work remains to be done.

If we undertake such a critical project, we will want to recall how long it took to disentangle politics and economics. To invent a national politics and organize the world in nation-states - and then to build a global economy. For all the agony that has come with success, building a national public politics across the planet had a strong emancipatory dimension - slaves, women, workers, peasants, colonial dominions obtained citizenship in relationship to the new institutional machinery of a national politics. It will not yield easily. It was equally difficult to build a global economy atop that political order. For all the vulnerability, instability, and inequality wrought by the effort, the global economy has also lifted hundreds of millions from poverty. It will not be unbuilt in a day. Building a new political economy for a global society will be equally difficult. The promise is equally large. The spirit of new approaches is to begin. 